\title{
A new characid fish, Hyphessobrycon hexastichos (Characiformes: Characidae) from Chapada dos Parecis, Mato Grosso, Brazil
}

\author{
Vinicius A. Bertaco and Tiago P. Carvalho
}

\begin{abstract}
A new characid species, Hyphessobrycon hexastichos, is described from the upper rio Tapajós, Mato Grosso, Brazil. The new species is distinguished from all other Hyphessobrycon species by the presence of black zigzag longitudinal lines between longitudinal rows of scales in the lateral of body, maxilla with 3-5 teeth, i,6 pelvic-fin rays, 18-22 branched anal-fin rays, 4 scale rows above and 3 scale rows below of lateral line, lateral line with 9-13 perforated scales, and 33-35 scales in a longitudinal series.
\end{abstract}

Uma nova espécie de caracídeo, Hyphessobrycon hexastichos é descrita para alto rio Tapajós, Mato Grosso, Brasil. A nova espécie distingue-se das demais espécies de Hyphessobrycon pela presença de linhas longitudinais pretas em ziguezague entre as faixas de escamas longitudinais na lateral do corpo, 3-5 dentes no maxilar, i,6 raios na nadadeira pélvica, 18-22 raios ramificados na nadadeira anal, 4 escamas acima e 3 escamas abaixo da linha lateral, 9-13 escamas perfuradas na linha lateral, e 33-35 escamas em uma série longitudinal.

Key words: Neotropical, Amazon basin, rio Tapajós, rio Juruena, Central Brazil, taxonomy.

\section{Introduction}

Hyphessobrycon Durbin is a speciose genus of small characid fishes, including more than one hundred valid species (Lima et al., 2003; Lima \& Moreira, 2003; Lucena, 2003; Bertaco \& Malabarba, 2005) distributed from southern Mexico to the río de La Plata in Argentina.

The genus was proposed by Durbin in Eigenmann (1908) as a subgenus of Hemigrammus Gill, differing from the latter by the absence of scales on the caudal fin. Hyphessobrycon was extensively revised by Eigenmann $(1918,1921)$ whose accounts still constitute the single comprehensive review of the genus. The anatomical diversity within Hyphessobrycon, and the high number of species involved are the major reasons for the lack of phylogenetic analyses dealing with its inter- and intra- relationships. The recognition of groups of species is based primarily on similarities of color patterns and fin shape (Géry, 1961; Géry, 1966; Géry, 1977; Weitzman \& Palmer, 1997). However, those authors only presented hypotheses of relationships for some of the possible species groups on Hyphessobrycon.

During a recent expedition to some of the south tributaries of the Amazon river in the Central and West regions of Brazil, a new characid species described below was collected in the upper rio Tapajós drainage.

\section{Methods and materials}

Counts and measurements were taken as described by Fink $\&$ Weitzman (1974) with the exception of the number of scale rows below lateral line that were counted from the scale row ventral of the lateral line to the scale row closest to the first pelvic-fin ray. Vertebral counts, supraneurals, gill-rakers of first arch, teeth and procurrent caudal-fin-ray counts were taken from cleared and stained specimens (c\&s) prepared according to the method of Taylor \& Van Dyke (1985). Teeth counts were also taken in all type specimens. Vertebral counts include the four vertebra of the Weberian apparatus, and the terminal centrum was counted as one vertebra. Lower and upper jaws of one c\&s paratype prepared for SEM (scanning electronic microscopy). Measurements were taken point to point with an electronic caliper on the left side of specimens when possible.

Specimens examined belong to the following institutions: MCP, Museu de Ciências e Tecnologia, Pontifícia Universidade Católica do Rio Grande do Sul, Porto Alegre; MZUSP, Museu de Zoologia, Universidade de São Paulo, São Paulo, and USNM, National Museum of Natural History, Smithsonian Institution, Washington D.C.

Laboratório de Ictiologia, Museu de Ciências e Tecnologia, Pontifícia Universidade Católica do Rio Grande do Sul, Av. Ipiranga 6681, Caixa Postal 1429, 90619-900 Porto Alegre, RS, Brazil. E-mails: ubertaco@pucrs.br (VAB), tiagobio2002@yahoo.com.br (TPC). 


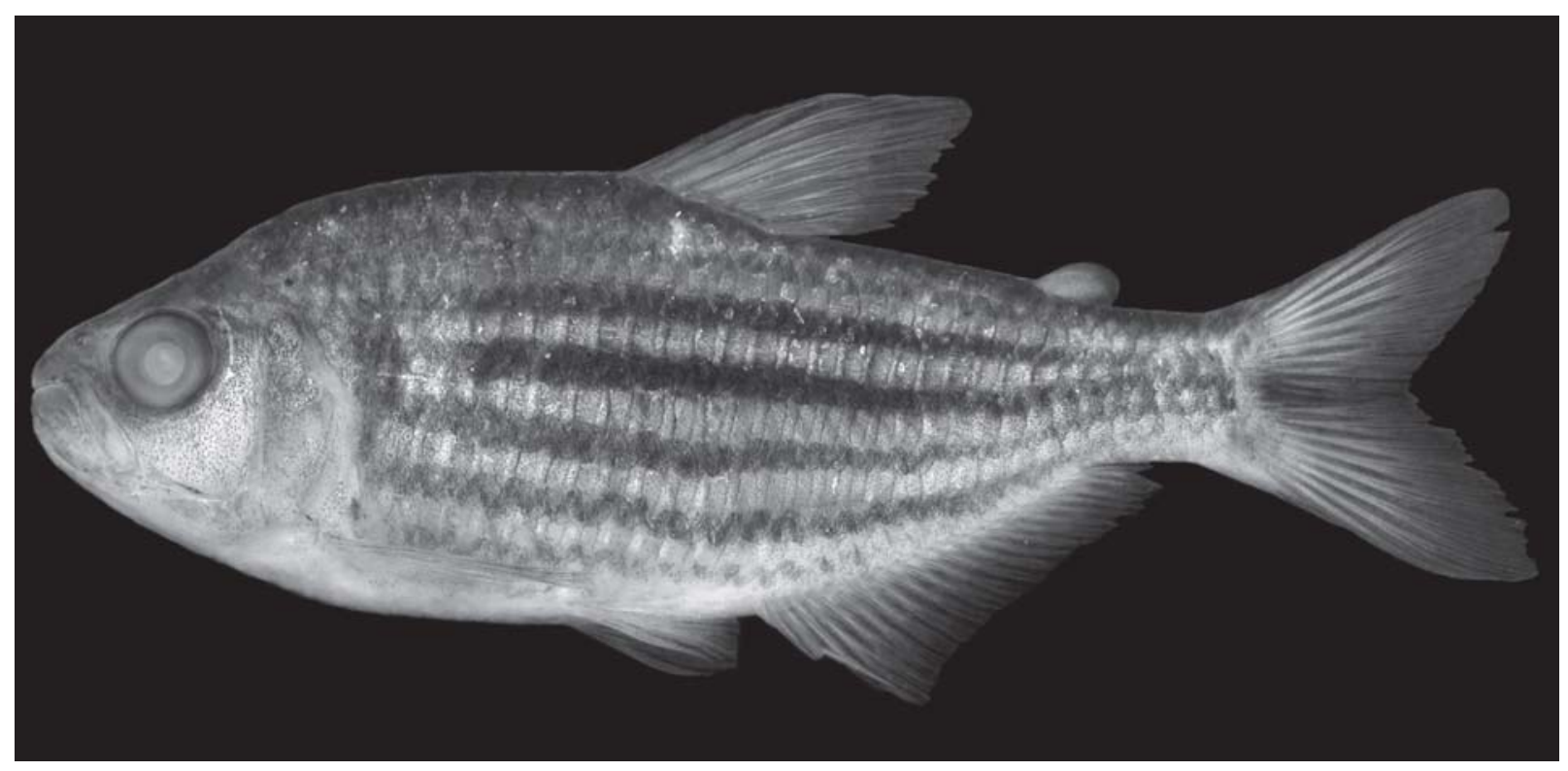

Fig. 1. Hyphessobrycon hexastichos, MCP 37648, holotype, $53.2 \mathrm{~mm}$ SL; Brazil, Mato Grosso, Comodoro, rio Mutum, tributary of rio Juruena, upper rio Tapajós drainage.

\section{Hyphessobrycon hexastichos, new species Figs. 1-2}

Moenkhausia agnesae, non Géry, 1965. -Notare (1994:6-7; misidentification; photo of live specimen).

Holotype. MCP 37648 (53.2 mm SL); Brazil, Mato Grosso, Comodoro, rio Mutum on road BR 364 to cidade de Vilhena, tributary of rio Juruena, upper rio Tapajós drainage, $13^{\circ} 05^{\prime} 08^{\prime \prime S} 59^{\circ} 53^{\prime} 32 " W, 14$ Jul 2004, J. F. Pezzi da Silva, V. A. Bertaco, F. C. Lima, \& P. C. Lehmann.

Paratypes. MCP 37649 (145, 4 c\&s, 16.9-46.8 mm SL), MZUSP 87242 (20, 19.0-45.0 mm SL), collected with the holotype.

Diagnosis. Hyphessobrycon hexastichos is distinguished from all remaining species of the genus, except $H$. uruguayensis (Fowler, 1943), by presence of black zigzag longitudinal lines between longitudinal body rows of scales in the lateral of body. The new species differs from $H$. uruguayensis by the number of scale rows between lateral line and pelvic-fin origin (3 vs. 4-6), number of maxillary teeth (3-5 vs. 6-11), number of perforated scales on lateral line series (9-13 vs. 6-8), and number and shape of teeth in the premaxillary inner row (5 pentacuspids vs. 6-7 tricuspids), respectively. Furthermore, the presence of bony hooks in all fins of $H$. uruguayensis (pers. obs.) is unknown on the fins of specimens of $H$. hexastichos.

Description. Morphometric data for H. hexastichos are summarized in Table 1. Body compressed and moderately deep; greatest body depth anterior to dorsal-fin origin. Dorsal body profile concave from nostril to supraocciptal spine, convex from that point to dorsal-fin origin; posteroventrally slanted at dorsal-fin base; straight from last dorsal-fin ray to adiposefin origin. Ventral profile of head convex. Ventral body profile convex from pectoral-fin origin to anal-fin origin. Body profile along anal-fin base posterodorsally inclined. Caudal peduncle profile nearly straight to slightly concave along both dorsal and ventral margins.

Snout convex from margin of upper lip to vertical through anterior nostrils. Head small. Mouth terminal. Maxilla extending posteriorly to vertical through middle of orbit, slightly curved, forming angle of $45^{\circ}$ with longitudinal axis of body. Anterodorsal border of maxilla concave, posterodorsal border slightly convex, anteroventral border concave, and posteroventral border convex. Maxilla slightly widened posteriorly.

Premaxilla with two tooth rows; outer row with 3-4, rarely 2 , pentacuspid teeth with central cusp larger; inner row teeth 5 , rarely 6 , gradually decreasing in length from first to fourth teeth, last tooth considerably smaller, with 5-9 cusps and central cusp longer and broader than other cusps. Three to 5 maxillary teeth, with 5-7 cusps, central cusp slightly longer. Four or 5 anterior-most dentary teeth larger, with 7 cusps, followed by 1-2 middle sized tooth with 5-7 cusps, and 6-7 teeth with 1-3 cusps or conical in shape; central cusp in all teeth two to three times longer and broader than remaining cusps. Cusp tips slightly curved posteriorly and towards inside of mouth (Fig. 2).

Dorsal-fin rays ii, $9(n=20)$, first unbranched ray approximately half length of second ray. Dorsal-fin origin located anterior to middle of SL and posterior to vertical through pelvic-fin origin. Fleshy flaps on anterior 5 dorsal-fin rays, attached to fin ray and extended over membrane between rays. Adipose-fin located approximately at vertical through insertion of 16th to 19th anal-fin rays bases. 


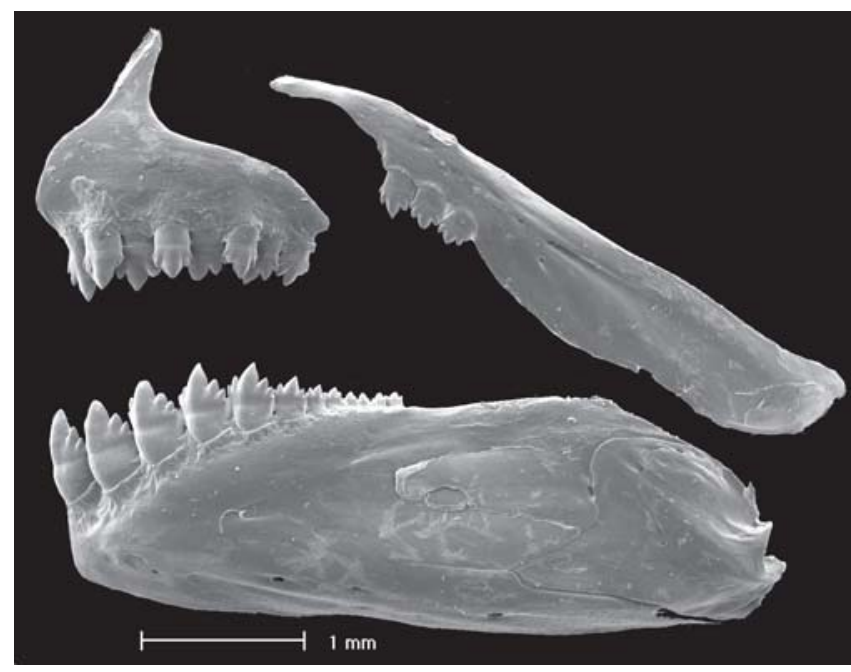

Fig. 2. Hyphessobrycon hexastichos, MCP 37649, paratype, $38.8 \mathrm{~mm}$ SL. Scanning electronic microscopy of left side upper and lower jaws teeth.

Anal-fin rays iii-iv, $18-22(\bar{x}=19.9, \mathrm{n}=20)$. First unbranched ray usually only apparent in cleared and stained specimens. Anal-fin distal margin slightly concave in some specimens. Anal-fin origin located posterior to vertical through base of last dorsal-fin ray. Pectoral-fin rays i, 9-10, rarely 12 $(\bar{x}=9.9, \mathrm{n}=20)$. Pelvic-fin rays i, $6(\mathrm{n}=20)$. Caudal-fin forked, with 19 principal rays. Dorsal procurrent rays $10-12$, and ventral procurrent rays 8-10 $(n=4)$.

Scales cycloid, moderately large. Lateral line incomplete, perforated scales 9-13 $(\bar{x}=10.7, \mathrm{n}=20)$. Longitudinal scale series including lateral-line scales 33-35 $(\bar{x}=33.8, \mathrm{n}=20)$. Scale rows between dorsal-fin origin and lateral line $4(\mathrm{n}=$ $20)$; scale rows between lateral line and pelvic-fin origin $3(\mathrm{n}=$ 20). Predorsal scales $8-11$, usually 9 , arranged in regular series $(\bar{x}=9.6, \mathrm{n}=20)$. Scales rows around caudal peduncle 14 .

Table 1. Morphometric data of holotype $(\mathrm{H})$ and paratypes of Hyphessobrycon hexastichos (MCP 37648, 1; MCP 37649, 14 of 145; MZUSP 87242, 5 of 20). SD = standard deviation.

\begin{tabular}{lcccc}
\hline Characters & H & Range & Mean & SD \\
\hline Standard length (mm) & 53.2 & $27.8-53.2$ & 38.7 & - \\
Predorsal distance & Percents of Standard length & & \\
Prepelvic distance & 55.3 & $52.1-55.3$ & 53.8 & 1.041 \\
Prepectoral distance & 50.0 & $48.2-51.9$ & 50.1 & 0.973 \\
Preanal distance & 29.5 & $26.8-29.9$ & 28.0 & 0.901 \\
Depth at dorsal-fin origin & 66.4 & $65.1-70.1$ & 66.9 & 1.591 \\
Caudal peduncle depth & 40.4 & $33.1-41.5$ & 39.0 & 1.926 \\
Caudal peduncle length & 13.2 & $10.8-13.5$ & 12.3 & 0.616 \\
Anal-fin base & 10.0 & $8.4-12.0$ & 10.2 & 0.844 \\
Dorsal-fin length & 30.8 & $26.0-31.3$ & 29.5 & 1.346 \\
Pelvic-fin length & 31.8 & $28.0-31.8$ & 29.6 & 1.117 \\
Pectoral-fin length & 16.0 & $14.6-16.9$ & 15.9 & 0.612 \\
Head length & 23.9 & $21.2-24.8$ & 23.1 & 0.961 \\
& 26.9 & $25.5-28.8$ & 26.9 & 0.875 \\
Snout length & 22.4 & $21.3-27.9$ & 24.7 & 1.797 \\
Upper jaw length & 46.2 & $43.0-50.8$ & 47.1 & 2.294 \\
Orbital diameter & 32.9 & $32.9-41.6$ & 37.9 & 2.200 \\
Interorbital width & 33.6 & $24.7-33.6$ & 30.2 & 2.459 \\
\hline
\end{tabular}

Scale sheath along anal-fin base with 7-11 scales in single series, extending posteriorly to base of fifth to ninth branched rays.

Precaudal vertebrae 14-15; caudal vertebrae 18; total vertebrae 32-33. Supraneurals 4-5. Gill-rakers 6-7/11 $(n=4)$.

Color in alcohol. Dorsal and dorsolateral portions of head and body dark brown. Portion midventral of body above anal fin with red-orange chromatophores in large specimens (38.3 $\mathrm{mm}$ SL). Infraorbital and opercular areas covered with scattered, dark chromatophores. Scales on lateral and ventral surface of body with dark brown chromatophores. Black zigzag longitudinal stripes between longitudinal body rows of scales in lateral of body. Specimens larger than $38.1 \mathrm{~mm}$ SL with five to six conspicuous longitudinal black stripes, two midlateral longitudinal black stripes densely pigmented above perforated scale series, one faint zigzag above these stripes, and three zigzag longitudinal stripes below perforated scale series. Specimens smaller than $38 \mathrm{~mm}$ SL with three or four dark stripes in midlateral body. One black humeral spot, narrow and vertically elongate, upper portion wider, located over first to third lateral line scales and extending over 2-3 horizontal series of scales, including lateral line. Silvery to violet midlateral body stripe extending from humeral region to caudal peduncle, between two longitudinal stripes above perforated scales. Caudal-fin median rays pigmented forming stripe. Small black chromatophores scattered over rays of all fins. Anal fin with small black chromatophores along its distal margin forming narrow stripe in some specimens (Fig. 1).

Color just after fixation. Color pattern similar to described for alcohol preserved specimens, except as follows. Some specimens examined soon after fixation in formalin, with all fins reddish. Lateral surface of body silvery. Body red-orange.

Sexual dimorphism. Secondary characters were not found on examined specimens. Mature gonads were not found on the four dissected cleared and stained specimens (MCP 37649 , $32.0-38.8 \mathrm{~mm} \mathrm{SL}$ ).

Distribution. Hyphessobrycon hexastichos is only known from rio Mutum, tributary of rio Juruena, in the headwaters of the rio Tapajós drainage, Chapada dos Parecis, Comodoro, Mato Grosso, Brazil.

Etymology. The specific epithet hexastichos is from the Greek, hexas, six, and stichos, meaning line or row, referring the presence of six conspicuous black zigzag longitudinal stripes between longitudinal body rows of scales in large specimens.

Ecological notes. All specimens of $H$. hexastichos were collected along the margin in semilentic stretches of a shallow river with clear water, with sand and scattered small stones on the bottom, and a small amount of riparian vegetation. Species collected syntopically with $H$. hexastichos were Aequidens 
epae, Cetopsorhamdia sp., Characidium sp., Eigenmannia virescens, Hemigrammus sp., Hyphessobrycon cf. vilmae, Leporinus sp., Megalechis thoracata, and Rhamdia sp.

\section{Discussion}

The new species is described in Hyphessobrycon according with the definition proposed by Durbin in Eigenmann (1908) and further elaborated by Eigenmann (1918): premaxillary teeth in two rows; maxillary teeth absent or reduced in number and restricted to the upper portion of its free margin; lateral line incomplete; adipose fin present, and caudal fin not covered with scales.

Weitzman \& Malabarba (1998) and Lucena (2003) pointed that there is no evidence that Hyphessobrycon is monophyletic, and recognition of monophyletic groups among Hyphessobrycon species is complicated by the difficulty in finding characters useful for hypothesis of relationships among the species. Weitzman \& Malabarba (1998) indicated that large characid genera such as Hyphessobrycon often have minimal morphological divergence useful for cladistic analyses of their species. Much of the information used to distinguish species are probably labile features such as variation in color pattern, counts and body proportions, that are little informative about phylogenetic relationships. Géry (1977: 458-459), proposed six artificial groups to the Hyphessobrycon species based on color pattern, $H$. hexastichos color pattern doesn't fit any of his group proposed.

Hyphessobrycon hexastichos possesses black zigzag longitudinal stripes between longitudinal body rows of scales in the lateral of body, a character uncommon among congeners but found only in larger specimens of $H$. uruguayensis (pers. obs.). The longitudinal stripes in $H$. uruguayensis are narrower, more conspicuous in middle portion of body, and some specimens can present only small black spots on lateral and dorsal surface of body. Hyphessobrycon hexastichos also differ from $H$. uruguayensis by the number of maxillary and premaxillary teeth (3-5 and 5 vs. 6-11 and 6-7), respectively. Furthermore, the presence of bony hooks in all fins of $H$. uruguayensis (pers. obs.) is unknown on the fins of specimens in H. hexastichos. Within the Tetragonopterinae sensu Géry (1977), such a pattern is also found in Astyanax lineatus (Perugia, 1891), A. kullanderi Costa (1995), A. superbus Myers (1942), Bario steindachneri (Eigenmann, 1893), species of Hollandichthys Eigenmann (1909), Markiana nigripinnis (Perugia, 1891), Moenkhausia agnesae Géry (1965), M. latissima (Eigenmann, 1908), M. rara Zarske, Géry \& Isbrücker (2004), M. simulata (Eigenmann, 1924), and Pseudochalceus lineatus Kner (1863). The lack of caudal-fin scales distinguishes $H$. hexastichos from all Markiana, Moenkhausia and Bario species, and the presence of an incomplete lateral line distinguishes it from Astyanax species. The elevated number of maxillary teeth (10 to 23) present in Hollandichthys and Pseudochalceus species distinguish these from $H$. hexastichos (3 to 5).

The number of pelvic-fin rays in most Hyphessobrycon species usually is i,7; but all specimens examined of $H$. hexastichos have only i,6; an uncommon count also to most genera of the Characidae. Hyphessobrycon hexastichos possess only three scale rows between lateral line and pelvic-fin origin, while most Hyphessobrycon species have four to six scale rows.

Five Hyphessobrycon species were previously described from the rio Tapajós drainage: $H$. pulchripinnis Ahl, 1937, $H$. cachimbensis Travassos, 1964, H. vilmae Géry, 1966, $H$. heliacus Moreira, Landim \& Costa, 2002, and H. scutulatus Lucena, 2003, the three last species from upper rio Tapajós drainage. None of these species possess black zigzag longitudinal stripes between longitudinal body rows of scales in the lateral of body as present in $H$. hexastichos.

The ichthyofauna of the rio Tapajós drainage is poorly known. Reports on the species composition of the drainage are nonexistent. During the collecting expedition to several affluents of rio Tapajós, rio Madeira, rio Purus and rio Paraguay drainages, $H$. hexastichos was collected only in the rio Mutum, tributary of the upper rio Tapajós, as also verified by Notare (1994).

Comparative material. Astyanax lineatus, MCP 15617 (5); Bario steindachneri, MCP 37500 (2); Hollandichthys multifasciatus, MCP 30560 (35); Hyphessobrycon heliacus, MCP 34551 (3); H. uruguayensis, MCP 36795 (13), MCP 37665 (1); H. scutulatus, MCP 32356 (129), paratypes; H. vilmae, MCP 30818 (27); Markiana nigripinnis, MCP 14489 (4); Moenkhausia agnesae, MCP 29466 (2); Pseudochalceus lineatus, USNM 287747 (5).

\section{Acknowledgments}

This paper benefited from comments and criticisms of Carlos Lucena, Luiz Malabarba and an anonymous reviewer. We are grateful to Pablo Lehmann (MCP) by the photograph of the holotype, and Flávio Lima (MZUSP) by the photograph of a specimen just after collection and for the reference of a color photograph in the magazineHabitat, Centro de Microscopia e Microanálises - CEMM, PUCRS for the SEM preparations, and to Alexandre Charcansky (MCP) by assistance in the Fig. 2. The specimens were collected during the Transcontinental Expedition organized by R. Reis (MCP) and sponsored by the All Catfish Species Inventory (NSF-DEB 0315963). The senior author is financially supported by the Coordenação de Aperfeiçoamento de Pessoal de Nível Superior (CAPES), and the junior author is supported by the Programa de Bolsa/Pesquisa para Alunos da PUCRS (BPA).

\section{Literature cited}

Bertaco, V. A. \& L. R. Malabarba. 2005. A new species of Hyphessobrycon (Teleostei: Characidae) from the upper rio Tocantins drainage, with bony hooks on fins. Neotropical Ichthyology, 3(1):83-88.

Eigenmann, C. H. 1908. Zoological results of the Thayer Brazilian Expedition. Preliminary descriptions of new genera 
and species of Tetragonopterid characins. Bulletin of the Museum of Comparative Zoology, 52(6):93-106.

Eigenmann, C. H. 1918. The American Characidae. Part 2. Memoirs of Museum of Comparative Zoology, 43:103-208.

Eigenmann, C. H. 1921. The American Characidae. Part 3. Memoirs of Museum of Comparative Zoology, 43:209-310.

Fink, W. L. \& S. H. Weitzman. 1974. The so-called Cheirodontin fishes of Central America with descriptions of two new species (Pisces: Characidae). Smithsonian Contributions to Zoology, 172:1-46.

Géry, J. 1961. Three new South American characids, Knodus savannensis, Hyphessobrycon herbertaxelrodi and Megalamphodus sweglesi, with a review of some Hyphessobrycon-groups of species (Contr. No. 16). Tropical Fish Hobbyist, 9(9):26-46.

Géry, J. 1966. Hyphessobrycon vilmae sp. n., a new tetra from the upper Juruena, Brazil, with keys to the Heterorhabduslike species. Ichthyologica/The Aquarium Journal, 63-70.

Géry, J. 1977. Characoids of the World. THF Publications, Neptune City, NJ, 672 p.

Lima, F. C. T, L. R. Malabarba, P. A. Buckup, J. F. Pezzi da Silva, R. P. Vari, A. Harold, R. Benine, O. T. Oyakawa, C. S. Pavanelli, N. A. Menezes, C. A. S. Lucena, M. C. S. L. Malabarba, Z. M. S. Lucena, R. E. Reis, F. Langeani, L. Casatti, V. A. Bertaco, C. Moreira \& P. H. F. Lucinda. 2003. Genera incertae sedis in Characidae. Pp. 134-141. In: R. E. Reis, S. O. Kullander \& C. J. Ferraris (Eds.). Check List of the Freshwater Fishes of South and Central America. Edipucrs, Porto Alegre, 729 p.
Lima, F. C. T. \& C. R. Moreira. 2003. Three new species of Hyphessobrycon (Characiformes: Characidae) from the upper rio Araguaia basin in Brazil. Neotropical Ichthyology, 1(1):21-33.

Lucena, C. A. S. 2003. New characid fish, Hyphessobrycon scutulatus, from the rio Teles Pires drainage, upper rio Tapajós system (Ostariophysi: Characiformes: Characidae). Neotropical Ichthyology, 1(2):93-96.

Notare, M. 1994. Peixes raros. Habitat, 1(1):6-7.

Reis, R. E., S. O. Kullander \& C. J. Ferraris (eds.). 2003. Check List of the Freshwater Fishes of South and Central America. Edipucrs, Porto Alegre, $729 \mathrm{p}$.

Taylor, W. R. \& G. C. Van Dyke. 1985. Revised procedures for staining and clearing small fishes and other vertebrates for bone and cartilage. Cybium, 9:107-119.

Weitzman, S. H. \& L. Palmer. 1997. A new species Hyphessobrycon (Teleostei: Characidae) from the Neblina region of Venezuela and Brazil, with comments on the putative 'rosy tetra clade'. Ichthyological Exploration of Freshwaters, 7(3):209-242.

Weitzman, S. H. \& L. R. Malabarba. 1998. Perspectives about the phylogeny and classification of the Characidae (Teleostei: Characiformes). Pp. 161-170. In: L. R. Malabarba, R. E. Reis, R. P. Vari, Z. M. S. Lucena, and C. A. S. Lucena (Eds.). Phylogeny and Classification of Neotropical Fishes. Edipucrs, Porto Alegre, 603 p.

Received June 2005 Accepted September 2005 